\title{
NEW ANTIBIOTICS, METHYLENOMYCINS A AND B
}

\section{STRUCTURES OF METHYLENOMYCINS A AND B}

\author{
Tatsuo Haneishi, Akira Terahara and Mamoru Arai \\ Fermentation Research Laboratories \\ Tadashi Hata and Chihiro Tamura \\ Central Research Laboratories, Sankyo Co., Ltd., Tokyo, Japan \\ (Received for publication February 28, 1974)
}

\begin{abstract}
The structure of methylenomycin A was studied physico-chemically and finally established by X-ray crystallographic analysis as 2-methylene-cyclopentane-3-one-4,5epoxy-4,5-dimethyl-1-carboxylic acid. The structure of methylenomycin B was also determined by a comparative study of the nuclear magnetic resonance spectra of methylenomycins A and B to be 4,5-epoxy-4,5-dimethyl-2-methylene-cyclopentane-3one, which makes it a decarboxylated derivative of methylenomycin A.
\end{abstract}

Methylenomycins A and B, produced by Streptomyces violaceoruber No. 2416, are new antibiotics with inhibitory activity against gram-positive and gram-negative bacteria, and especially, against Proteus. The taxonomy of the producing organism and production and characteristics of these antibiotics were reported in the previous paper. ${ }^{1)}$ The present paper deals with the structural elucidation of methylenomycins A and B.

\section{Structural Elucidation of Methylenomycin A}

Methylenomycin A (I), $\mathrm{C}_{9} \mathrm{H}_{10} \mathrm{O}_{4}\left(\mathrm{M}^{+} 182\right)$, is an acidic (pKa' 3.65), lipophilic, colorless crystalline substance; m.p. $115^{\circ} \mathrm{C}\left(\mathrm{dec}\right.$.), $[\alpha]_{D}^{30}+42.3^{\circ}\left(\mathrm{c} 1, \mathrm{CHCl}_{3}\right)$. The IR spectrum of methylenomycin A showed absorptions at $3500 \sim 2500$ and $1720 \mathrm{~cm}^{-1}$ due to a carboxyl group. An enol or cisoid carbonyl group absorption was found at $1740 \mathrm{~cm}^{-1}$ and an absorption band at 1650 $\mathrm{cm}^{-1}$ indicated the existence of an unsaturated double bond. The NMR spectrum taken at $100 \mathrm{MHz}$ in $\mathrm{CDCl}_{3}$ showed two methyl signals at $\delta 1.58$ and 1.48 , two protons due to an ethylenic double bond at $\delta 5.65$ (doublet $\mathrm{J}=1.7 \mathrm{~Hz}$ ) and 6.27 (doublet, $\mathrm{J}=1.9 \mathrm{~Hz}$ ), one proton coupled with two protons of the terminal methylene group at $\delta 3.82$ (multiplet, $\mathrm{J}=1.9$ and 1.7 $\mathrm{Hz}$ ) and one proton exchangeable with $\mathrm{D}_{2} \mathrm{O}$, due to the carboxyl group, at $\delta 9.95$. The UV spectrum of methylenomycin A showed a maximum at $224 \mathrm{~m} \mu(\approx 6,300)$, which indicated the possible existence of an $\alpha, \beta$-unsaturated carbonyl function. The relationship between the carbonyl group and the terminal methylene in the molecule was provided by the reduction of each functional group.

Hydrogenation of methylenomycin A on palladium-carbon yielded dihydroderivative (III), $\mathrm{C}_{8} \mathrm{H}_{12} \mathrm{O}_{4}, m / e$ 184, in which the presence of three methyl groups was noted in the NMR spectrum $(\delta=1.55,1.44$ and 1.05$)$ and characteristics of methylenomycin A, such as its UV absorption maximum at $224 \mathrm{~nm}$ and IR absorption band at $1650 \mathrm{~cm}^{-1}$ due to the conjugated double bond, disappeared.

On $\mathrm{NaBH}_{4}$ reduction, compound III afforded quantitatively a crystalline monohydroxy derivative (VII), $\mathrm{C}_{9} \mathrm{H}_{14} \mathrm{O}_{4}$, m/e 186, which showed only the IR absorption band in the carbonyl 
region at $1710 \mathrm{~cm}^{-1}$, attributable to the carboxyl group. This compound VII was readily regenerated to compound III by JONES oxidation. In the NMR spectrum of compound VII, the $\mathrm{C}_{2}-\mathrm{H}$ multiplet, centered at $\delta 2.25$, was coupled to the $\mathrm{C}_{3}-\mathrm{H}$, at $\delta 3.92$ with a coupling constant $\mathbf{J}=5.0 \mathrm{~Hz}$, and to $\mathrm{C}_{1}-\mathrm{H}$, at $\delta 3.07$ with coupling constant $\mathbf{J}=7.5 \mathrm{~Hz}$. A similar relationship was also observed between $\mathrm{C}_{1}-\mathrm{H}(\delta 3.44)$ and $\mathrm{C}_{2}-\mathrm{H}(\delta$ 2.83) in compound III $(\mathrm{J}=8.0 \mathrm{~Hz})$.

Reaction of methylenomycin $\mathrm{A}$ with diazomethane provided a methyl ester $\mathrm{C}_{2}$-2,3-pyrazoline derivative (IV). The diazomethane adduct was further converted to $\mathrm{C}_{2}$-ethylidene methyl ester (XI) and to $\mathrm{C}_{2}$-cyclopropane methyl ester (XII) on heating the adduct in toluene at $120^{\circ} \mathrm{C}$ for 30 minutes.

Treatment of methylenomycin A with bromine yielded crystalline dibromo-methylenomycin A (VI). Its NMR spectrum in $\mathrm{CDCl}_{3}$ showed that addition of bromine to the terminal methylene resulted in alteration of two protons of the terminal methylene to an A B type quartet and also gave a sharp singlet signal corresponding to a proton attached to the carbon atom bearing the carboxyl group.

These facts indicated that methylenomycin A possessed a terminal methylene conjugated to a ketone group and the NMR splitting patterns of $\mathrm{C}_{2}-\mathrm{H}$ in hydrogenated derivative (III) indicated the presence of partial structural unit $\mathrm{O}=\stackrel{\mathrm{C}}{\mathrm{C}}-\mathrm{CH}\left(\mathrm{CH}_{3}\right)-\stackrel{\text { C }}{\mathrm{H}}-\mathrm{COOH}$ in the molecule. Meanwhile, the product derived from compound III by alkaline degradation, $\mathrm{C}_{5} \mathrm{H}_{6} \mathrm{O}_{4}$, m.p. 202 204 ${ }^{\circ} \mathrm{C}$ was identified with mesaconitic acid (methyl fumaric acid) (XXX) by comparative IR and NMR spectra studies with an authentic preparation.

These results also supported the presence of a partial structural unit

$$
\mathrm{O}=\stackrel{!}{\mathrm{C}}-\mathrm{C}\left(=\mathrm{CH}_{2}\right)-\stackrel{+}{\mathrm{CH}}-\mathrm{COOH}
$$

in methylenomycin A.

To account for the remaining two unsaturations, methylenomycin $\mathrm{A}$ was examined to ascertain the arrangement of the remaining one oxygen atom, two carbon atoms bearing no

Chart 1

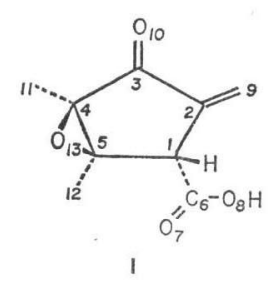

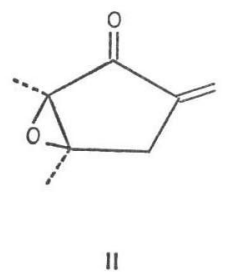
hydrogen atom, and two methyl groups.

By treatment of compound III with $85 \%$ phosphoric acid at $60^{\circ} \mathrm{C}$ for 30 minutes, a neutral crystalline compound, $\mathbf{X}, \mathrm{C}_{9} \mathrm{H}_{12} \mathrm{O}_{4}$ was obtained. Its IR spectrum showed a characteristic absorption band at $1800 \mathrm{~cm}^{-1}$, which was consistent with the presence of a $\beta$ lactone. The NMR spectrum showed a proton at $\mathrm{C}_{1}$ of $\delta 3.00$ (doublet, $\mathrm{J}=4.5 \mathrm{~Hz}$ ), a proton at $\mathrm{C}_{2}$ of $\delta 3.05$ (multiplet $\mathrm{J}=4.5$ and $7.0 \mathrm{~Hz}$ ), a methyl group at $\mathrm{C}_{2}$ of $\delta 1.20$ (doublet, $\mathbf{J}=7.0 \mathrm{~Hz}$ ), and two singlet methyl groups of $\delta 1.33$ and 1.56. On the other hand, compound VIII treated with alkaline aqueous methanol provided compound XXVII $\left(\mathrm{C}_{10} \mathrm{H}_{14} \mathrm{O}_{4}\right)$. Its NMR spectrum showed the absence of a proton at $\mathrm{C}_{1}$ observed in the starting material as a doublet, and the alteration of multiplet to quartet on a proton at $\mathrm{C}_{2}(\mathrm{~J}=8.0 \mathrm{~Hz})$.

The formation of these two compounds suggested cleavage of an epoxide ring in methylenomycin A by treatment with acid or base. Therefore, taking into consideration the remain- 
ing group to be placed: two methyl groups, two carbon atoms bearing no hydrogen atom, and one unsaturation, structure I was deduced as the most possible for methylenomycin A.

Independently, methylenomycin A was submitted to X-ray crystallographic analysis. The crystal data of this compound are: $\mathrm{a}=$ 7.34, b=10.00, c $=12.22 \AA$, space group $\mathrm{P} 22_{1} 2_{1}, \quad \mathrm{D}_{\text {obs }}=1.34 \mathrm{~g} / \mathrm{cm}^{3}, \quad \mathrm{D}_{\text {ealc }}=1.35 \mathrm{~g} / \mathrm{cm}^{3}$. Reflection data were collected on a Rigaku four-circle auto diffractometer up to a $2 \theta$ limit of $60^{\circ}$ using Mo-K $\alpha$ radiation. A total of 875 reflections were used for the subsequent structure analysis. By the application of the tangent formula of HAUPTOMAN and KARLE ${ }^{2)}$, the structure was satisfactorily determined. The five reflections taken as starting phases were as follows: $5,0,14=0^{\circ}, \quad 7,0,11=90^{\circ}$, $7,7,0=-90^{\circ}, 6,1,0=90^{\circ}$, and $0,7,3=\mathrm{a} . \quad$ The 6 peaks of the 13 highest peaks on the resulting E-map (as $\mathrm{a}=90^{\circ}$ ), corresponded to a part

Table 1. Fractional coordinates of methylenomycin A

\begin{tabular}{|c|c|c|c|}
\hline Atom & $\mathrm{X} / \mathrm{a}$ & $\mathrm{Y} / \mathrm{b}$ & $\mathrm{Z} / \mathrm{c}$ \\
\hline C 1 & 0.2226 & 0.3151 & 0.3368 \\
\hline C 2 & 0.2656 & 0.4341 & 0.2667 \\
\hline C 3 & 0.3065 & 0.3895 & 0.1536 \\
\hline C 4 & 0.2548 & 0.2430 & 0.1445 \\
\hline C 5 & 0.2033 & 0.1980 & 0.2554 \\
\hline C 6 & 0.3725 & 0.2826 & 0.4191 \\
\hline C 7 & 0.3440 & 0.2475 & 0.5108 \\
\hline C 8 & 0.5371 & 0.2955 & 0.3777 \\
\hline C 9 & 0.2615 & 0.5550 & 0.2968 \\
\hline O 10 & 0.3690 & 0.4557 & 0.0808 \\
\hline C 11 & 0.3158 & 0.1546 & 0.0529 \\
\hline C 12 & 0.2054 & 0.0562 & 0.2923 \\
\hline O 13 & 0.0636 & 0.2360 & 0.1772 \\
\hline H 1 & 0.103 & 0.322 & 0.378 \\
\hline H 8 & 0.617 & 0.248 & 0.433 \\
\hline $\mathrm{H} \quad 9 \mathrm{~A}$ & 0.300 & 0.616 & 0.274 \\
\hline $\mathrm{H} 9 \mathrm{~B}$ & 0.244 & 0.588 & 0.367 \\
\hline $\mathrm{H} 11 \mathrm{~A}$ & 0.433 & 0.177 & 0.040 \\
\hline H 11B & 0.255 & 0.205 & 0.012 \\
\hline $\mathrm{H} 11 \mathrm{C}$ & 0.239 & 0.078 & 0.029 \\
\hline H 12A & 0.341 & 0.053 & 0.346 \\
\hline H 12B & 0.211 & 0.000 & 0.245 \\
\hline $\mathrm{H} 12 \mathrm{C}$ & 0.110 & 0.054 & 0.336 \\
\hline
\end{tabular}

Table 2. Bond lengths (a) and angles (b) of methylenomycin A

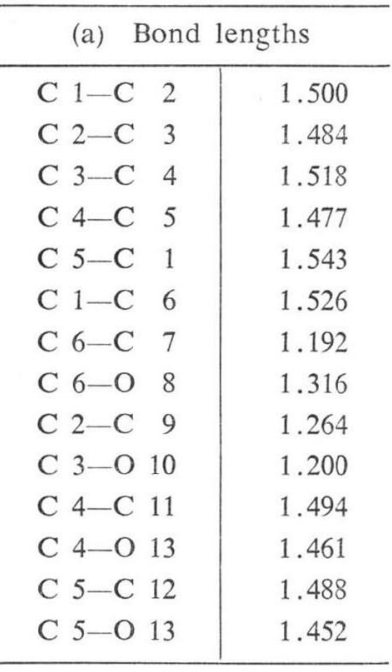

(b) Bond angles

\begin{tabular}{|c|c|}
\hline C $2-\mathrm{C} 1-\mathrm{C} 5$ & 104.7 \\
\hline C $2-\mathrm{C} \quad 1-\mathrm{C} \quad 6$ & 113.2 \\
\hline C $5-$ C $1-$ C 6 & 109.3 \\
\hline C $1-$ C $2-\mathrm{C} 3$ & 109.6 \\
\hline C $1-\mathrm{C} \quad 2-\mathrm{C} \quad 9$ & 126.0 \\
\hline C $3-$ C $2-$ C 9 & 124.3 \\
\hline C $2-\mathrm{C} 3-\mathrm{C} 4$ & 108.0 \\
\hline C $2-\mathrm{C} \quad 3-\mathrm{O} 10$ & 127.1 \\
\hline C $4-\mathrm{C} \quad 3-\mathrm{O} 10$ & 125.0 \\
\hline C $3-\mathrm{C} 4-\mathrm{C} 5$ & 106.9 \\
\hline C $3-\mathrm{C} 4-\mathrm{C} 11$ & 123.4 \\
\hline $\mathrm{C} 3-\mathrm{C} 4-\mathrm{O} 13$ & 105.4 \\
\hline C $5-\mathrm{C} \quad 4-\mathrm{C} 11$ & 125.7 \\
\hline C 5-C 4-O 13 & 59.2 \\
\hline $\mathrm{C} 11-\mathrm{C} \quad 4-\mathrm{O} 13$ & 117.7 \\
\hline C $1-\mathrm{C} \quad 5-\mathrm{C} 4$ & 109.7 \\
\hline C $1-\mathrm{C} \quad 5-\mathrm{C} 12$ & 121.8 \\
\hline C $1-\mathrm{C} \quad 5-\mathrm{O} 13$ & 106.9 \\
\hline C $4-\mathrm{C} \quad 5-\mathrm{C} 12$ & 124.4 \\
\hline C $4-$ C $5-\mathrm{O} 13$ & 59.8 \\
\hline $\mathrm{C} 12-\mathrm{C} \quad 5-\mathrm{O} 13$ & 117.1 \\
\hline C $1-\mathrm{C} \quad 6-\mathrm{O} \quad 7$ & 123.7 \\
\hline C $1-\mathrm{C} \quad 6-\mathrm{O} \quad 8$ & 112.8 \\
\hline $\mathrm{O} \quad 7-\mathrm{C} \quad 6-\mathrm{O} \quad 8$ & 123.4 \\
\hline C $4-\mathrm{O} 13-\mathrm{C} 5$ & 61.0 \\
\hline
\end{tabular}


of the molecular feature with reasonable bond lengths and angles. Successive Fourier and least-squares refinements using these peaks, established the whole molecular structure as I, and the R-factor dropped to $7.9 \%$. The final atomic parameters and the bond lengths and angles are listed in Tables 1 and 2 (a), (b), respectively. Figure 1(a), (b) shows the stereographic views of this compound in which the relation between the carboxylic acid group and the epoxide group is trans. The carboxylic acid group is hydrogen-bonded to another carboxylic acid group of the neighboring molecule along the b-axis with a value of $2.67 \AA$. Very short intermolecular atomic contact is observed at C9.... 13 , with a value of $3.01 \AA$. The dihedral angle between the five membered ring and the epoxide group is $86^{\circ}$. The molecular structure of methylenomycin A thus determined explains reasonably all its physical and chemical properties.

\section{Structural Elucidation of Methylenomycin B}

The structural investigation of methylenomycin B was mainly carried out by comparative studies of its NMR spectral data with those of methylenomycin A. Two signals, a multiplet

Chart 2
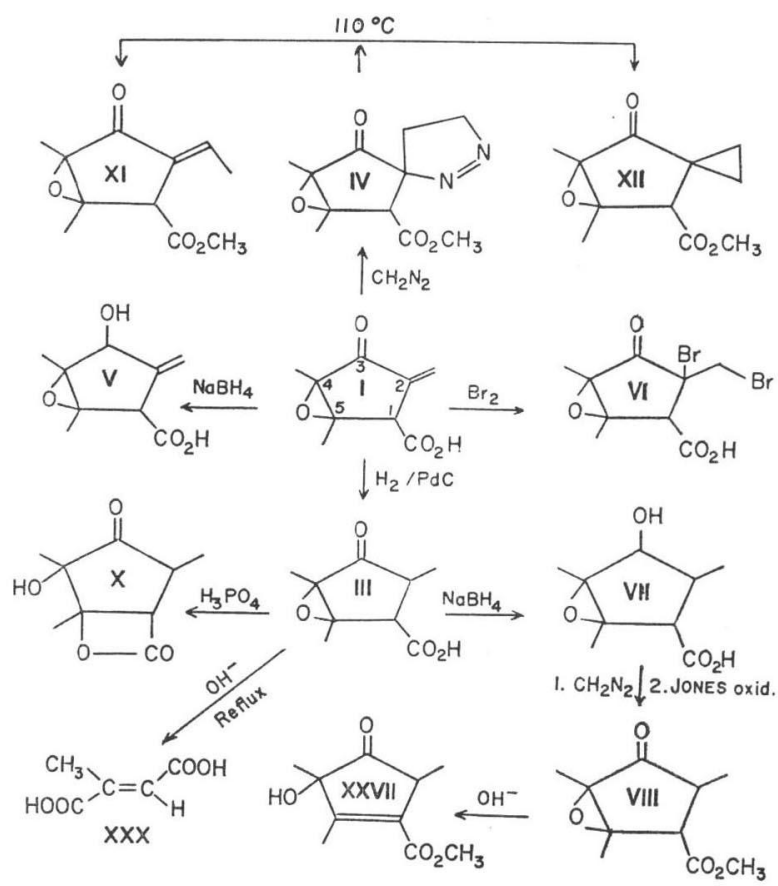
at $\delta 3.82$ due to a proton on a carbon atom bearing carboxyl group and a singlet at $\delta 9.95$ due to carboxyl group were only found in methylenomycin A, while a methylenic proton at $\delta 3.08$ was only observed in methylenomycin B. All of the other eight protons (terminal methylene, and two methyl groups) were common to these two antibiotics.

From these results and its other physical and chemical properties, the structure of methylenomycin B was determined as II, a decarboxylated form of methylenomycin A.

\section{Experimental}

Melting points were measured by a Yamato micro-melting point apparatus and were uncorrected. UV spectra were run on a Hitachi 124 recording spectrophotometer and IR spectra on a Hitachi infrared spectrophotometer. Optical rotations were determined with PerkinElmer 141 polarimeter.

All NMR spectra were run on a Varian model NMR spectrometer and chemical shifts were measured to an internal standard, TMS, and were recorded as $\delta$ values.

Compound III. Hydrogenation of compound I $(550 \mathrm{mg})$ in $20 \mathrm{ml}$ of acetone over Pdcarbon $(200 \mathrm{mg})$ was carried out at atmospheric pressure for 30 minutes at room temperarure. Approximately one equivalent of hydrogen was absorbed. The reaction mixture was filtered to remove the catalyst and concentrated to dryness. The residue was purified on a preparative silica gel thin-layer plate (Merck Co., Ltd., Silica gel plate $2.0 \mathrm{~mm}, \mathrm{~F}_{254}$ ) using a mixture of benzene-MeOH-AcOH $(45: 8: 4)$ as a solvent system and the band was eluted with the same solvent mixture. On evaporation of the solvents, $420 \mathrm{mg}$ of III was obtained as colorless plates; mp $78 \sim 79^{\circ} \mathrm{C}, m / e$ 184, IR $\nu_{\max }^{\mathrm{CHC} 1_{3}} 1750,1710 \mathrm{~cm}^{-1}$; UV, end absorption; NMR, $\delta_{\mathrm{ppm}}^{\mathrm{CDO}_{3}}$ $1.05\left(\mathrm{~d}, 3 \mathrm{H},-\stackrel{\mathrm{C}}{\mathrm{C}}-\underline{\mathrm{CH}}_{3}, \mathrm{~J}=8.0 \mathrm{~Hz}\right), 2.83\left(\mathrm{~m}, 1 \mathrm{H}, \stackrel{-}{\mathrm{C}} \mathrm{H}-\mathrm{CH}_{3}, \mathrm{~J}=7.5\right.$ and $\left.8.0 \mathrm{~Hz}\right), 3.44(\mathrm{~d}, 1 \mathrm{H}$, HOOC- $\stackrel{\text { CH}}{ }-\stackrel{\prime}{C} H-\mathrm{CH}_{3}, \quad J=7.5 \mathrm{~Hz}$ ) and 9.74 (bs, $1 \mathrm{H}, \underline{\mathrm{HOOC}-}$ ). Found: $\mathrm{C}, 59.21 ; \mathrm{H}, 6.75 \%$. Calcd. for $\mathrm{C}_{8} \mathrm{H}_{12} \mathrm{O}_{4}: \mathrm{C}, 58.69 ; \mathrm{H}, 6.57 \%$.

Compound IV. Compound I (1.2 g) was dissolved in $10 \mathrm{ml}$ of ethylacetate and ethereal diazomethane was added until bubbling ceased and the solution was allowed to stand for 2 hours at room temperature with occasional stirring. After removal of the solvent under reduced pressure, the residue was washed with $n$-hexane, and then it was purified by preparative silica gel thin-layer plate using a solvent system of EtOAc-acetone (9:1) and elution with acetone. Finally IV was obtained as colorless needles $(890 \mathrm{mg}) ; \mathrm{mp} 95 \sim 96^{\circ} \mathrm{C} ; \mathrm{m} / \mathrm{e} 238$; IR $\nu_{\max }^{\mathrm{KBr}} .1745,1735,1555,1348$ and $1170 \mathrm{~cm}^{-1} ; \mathrm{NMR} \delta_{\mathrm{ppm}}^{\mathrm{CDCl}_{3}} 3.77\left(\mathrm{~s}, 3 \mathrm{H},-\mathrm{COOCH}_{3}\right), 4.53(\mathrm{~m}, 2 \mathrm{H}$, $-\mathrm{CH}_{2}-\mathrm{CH}_{2}-\mathrm{N}=, \mathrm{J}=18,8$ and $\left.8 \mathrm{~Hz}\right), 1.75\left(\mathrm{~m}, 2 \mathrm{H},-\mathrm{CH}_{2}-\mathrm{CH}_{2}-\mathrm{N}=, \mathrm{J}=18,8\right.$ and $\left.8 \mathrm{~Hz}\right)$ and 3.25 (s, $1 \mathrm{H}, \mathrm{CH}_{3} \mathrm{OOC}-\underline{\mathrm{CH}}-$ ). Found: $\mathrm{C}, 55.58 ; \mathrm{H}, 5.80 ; \mathrm{N}, 11.93 \%$. Calcd. for $\mathrm{C}_{11} \mathrm{H}_{14} \mathrm{O}_{4} \mathrm{~N}_{2}: \mathrm{C}, 55.45$, $\mathrm{H}, 5.92 ; \mathrm{N}, 11.76 \%$.

Compound V. Compound I $(3.0 \mathrm{~g})$ dissolved in $20 \mathrm{ml}$ of EtOH, was reduced with $0.6 \mathrm{~g}$ of $\mathrm{NaBH}_{4}$ at $0^{\circ} \mathrm{C}$. After addition of $10 \mathrm{ml}$ of distilled water, the reaction mixture was concentrated to $5 \mathrm{ml}$, acidified with dil. $\mathrm{HCl}$ to $\mathrm{pH} 2.0$, saturated with sodium chloride and extracted with EtOAc. The extract was concentrated to yield $2.9 \mathrm{~g}$ of $\mathbf{V}$ as colorless oil; mie 184, UV end absorption; NMR, $\delta_{\mathrm{pmm}}^{\mathrm{CDC1}} 3.48$ (s, $\left.1 \mathrm{H},-\underline{\mathrm{C}} \mathrm{H}-\mathrm{COOH}\right), 4.58$ (bs $\left.1 \mathrm{H},-\stackrel{!}{\mathrm{C}} \mathrm{H}-\underline{\mathrm{OH}}\right)$. Found: $\mathrm{C}$, $59.0 ; \mathrm{H}, 6.65 \%$. Calcd. for $\mathrm{C}_{8} \mathrm{H}_{12} \mathrm{O}_{4}$ : C, 58.69; $\mathrm{H}, 6.57 \%$.

Compound VI. To compound I $(200 \mathrm{mg})$ dissolved in $20 \mathrm{ml}$ of $\mathrm{CHCl}_{3}$ was added an appropriate aliquot of bromine solution at room temperature and the reaction mixture was stirred for one hour. After evaporation of the solvent under vacuum, the resultant crystalline residue was recrystallized from benzene as colorless needles $(210 \mathrm{mg}) ; \mathrm{mp} 124^{\circ} \mathrm{C}$; IR $\nu_{\max }^{\mathrm{CHCl}_{3}}$ $3500 \sim 2500 \mathrm{~cm}^{-1}, 1705 \mathrm{~cm}^{-1}$. Found: C, 32.08; H, 2.93; $\mathrm{Br}, 46,57 \%$. Calcd. for $\mathrm{C}_{9} \mathrm{H}_{10} \mathrm{Br}_{2} \mathrm{O}_{4}$ : C, 31.58; H, 2.92; $\mathrm{Br}, 46.78 \%$. 
Compound VII. Comopund III $(1.0 \mathrm{~g})$, dissolved in $30 \mathrm{ml}$ of $\mathrm{EtOH}$, was reduced with 400 $\mathrm{mg}$ of $\mathrm{NaBH}_{4}$ at $0^{\circ} \mathrm{C}$. After addition of $30 \mathrm{ml}$ of distilled water to the reaction mixture, it was concentrated to $15 \mathrm{ml}$ under vacuum and acidified with dil. $\mathrm{HCl}$ to $\mathrm{pH} 2.0$ and extracted with EtOAc. The extract was washed with water saturated with sodium chloride and concentrated to dryness. The crude compound VII thus obtained was purified by column chromatography on silica gel packed with benzene, eluted with the same solvent to obtain compound VII as colorless needles $(420 \mathrm{mg}) ; \mathrm{mp}, 123 \sim 124^{\circ} \mathrm{C}$; m'e 186; IR $\nu_{\max }^{\mathrm{CHOl}_{3}} \quad 3500 \sim 2500,1700$ $\mathrm{cm}^{-1}$; NMR $\delta_{\mathrm{D} p \mathrm{~m}}^{\mathrm{CDC} 1_{3}} 1.0\left(\mathrm{~d}, 3 \mathrm{H},-\stackrel{\mathrm{C}}{\mathrm{C}} \mathrm{H}-\mathrm{CH}_{3}, \mathrm{~J}=7.5 \mathrm{~Hz}\right), 2.25\left(\mathrm{~m}, 1 \mathrm{H},-\mathrm{CH}(\mathrm{OH})-\underline{\mathrm{CH}}\left(\mathrm{CH}_{3}\right)-\mathrm{CH}(\mathrm{COOH})-\right.$, $\mathbf{J}=7.5,7.5$ and $5.0 \mathrm{~Hz}), 3.07\left(\overline{\mathrm{d}, 1 \mathrm{H}},-\mathrm{CH}(\mathrm{COOH})-\mathrm{CH}\left(\mathrm{CH}_{3}\right)-, \mathrm{J}=7.5 \overline{\mathrm{Hz}}\right)$, and $3.92(\mathrm{~d}, 1 \mathrm{H}$, $\left.-\mathrm{CH}(\mathrm{OH})-\mathrm{CH}\left(\mathrm{CH}_{3}\right)-, \mathrm{J}=5.0 \mathrm{~Hz}\right)$. Found: C, 57.94, H, $7.58 \%$. Calcd. for $\mathrm{C}_{9} \mathrm{H}_{14} \mathrm{O}_{4}: \mathrm{C}$, $58.05 ; \mathrm{H}, 7.58 \%$.

Compound VIII. Ethereal diazomethane was added to compound VII (400 mg) dissolved in $10 \mathrm{ml}$ of $\mathrm{CHCl}_{3}$ until the end of bubbling. The resultant methyl ester of compound VII was further treated with JoNEs reagent to obtain compound VIII. JoNEs oxidation was carried out by addition of JONES reagent $(2 \mathrm{ml})$ to the acetone solution of methyl ester of compound VII $(3 \mathrm{ml})$. The upper layer of the reaction mixture was separated and washed with water saturated with sodium chloride. The product was purified on a silica gel column packed with benzene followed by elution with the same solvent. Compound VIII was obtained as colorless oil $(305 \mathrm{mg}) ; m / e$ 198; IR $\nu_{\mathrm{max}}^{\mathrm{CHCl}_{3}} 1745,1710 \mathrm{~cm}^{-1} ; \mathrm{NMR} \delta_{\mathrm{ppm}}^{\mathrm{CDCl}_{3}} 3.78$ (s, $3 \mathrm{H}$, $-\mathrm{COOCH}_{3}$ ). Found: C, 60.55; $\mathrm{H}, 7.14 \%$. Calcd. for $\mathrm{C}_{10} \mathrm{H}_{14} \mathrm{O}_{4}: \mathrm{C}, 60.59 ; \mathrm{H}, 7.12 \%$.

Compound $\mathbf{X}$. Compound III $(1.0 \mathrm{~g})$ was treated with $85 \%$ phosphoric acid at $80^{\circ} \mathrm{C}$ for 20 minutes and the reaction mixture was extracted with EtOAc. The extract was concentrated to dryness. Then compound $\mathbf{X}$ was purified on the preparative thin-layer plate of silica gel, developing with EtOAc. Elution of the thin-layer plate with EtOAc gave colorless needles of $\mathrm{X}(272 \mathrm{mg}) ; \mathrm{mp} 86 \sim 89^{\circ} \mathrm{C}$; $m / e$ 184; IR $\nu_{\max }^{\mathrm{CHCl}_{3}} 3600,3400,1800,1775,1040,915 \mathrm{~cm}^{-1}$; NMR

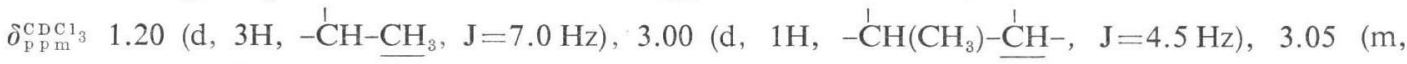
$1 \mathrm{H},-\mathrm{CH}\left(\mathrm{CH}_{3}\right)-\stackrel{\mathrm{C}}{\mathrm{C}} \mathrm{H}-, \mathrm{J}=7.0$ and $\left.4.5 \mathrm{~Hz}\right)$. Found: C, 58.11; $\mathrm{H}, 6.63 \%$. Calcd. for $\mathrm{C}_{9} \mathrm{H}_{12} \mathrm{O}_{4}$ : C, $58.69 ; \mathrm{H}, 6.57 \%$.

Compound XI and XII. Compound IV (700 mg) was treated with toluene at $110^{\circ} \mathrm{C}$ for 30 minutes. Compound XI and XII (1:1 mixture) was obtained with simultaneous liberation of nitrogen. They were separated on a preparative thin-layer plate of silica gel by developing with the solvent system of EtOAc-benzene (1:9). Finally $260 \mathrm{mg}$ of compound XI and $244 \mathrm{mg}$ of compound XII were obtained, respectively.

Compound XI. Oil; $m^{\prime} e$ 210; IR $\nu_{\max }^{\mathrm{Liq}} 1740,1720,1625 \mathrm{~cm}^{-1}$; UV $\lambda_{\max }^{\mathrm{MeOH}} 240 \mathrm{~nm}(\varepsilon 7600)$; NMR $\delta_{\mathrm{DPm}}^{\mathrm{CDCl}_{3}} 2.14\left(\mathrm{dd}, 3 \mathrm{H},-\mathrm{CH}\left(\mathrm{CH}_{3}\right)=\mathrm{C}\left(\mathrm{CH}-\mathrm{COOCH}_{3}\right)\right), \quad \mathbf{J}=7.5$ and $\left.2.0 \mathrm{~Hz}\right), 3.74$ (bs, $1 \mathrm{H}$ $\left.\mathrm{CH}\left(\mathrm{CH}_{3}\right)=\stackrel{\text { C }-}{\mathrm{C}} \mathrm{H}-\mathrm{COOCH}_{3}\right), 4.30\left(\mathrm{~m}, 1 \mathrm{H}, \underline{\mathrm{CH}}\left(\mathrm{CH}_{3}\right)=\stackrel{\mathrm{C}}{\mathrm{C}}, \mathbf{\mathrm { J }}=7.5\right.$ and $\left.1.5 \mathrm{~Hz}\right)$. Found: $\mathrm{C}$, 63.26; $\mathrm{H}, 6.79 \%$. Calcd. for $\mathrm{C}_{11} \mathrm{H}_{14} \mathrm{O}_{4}: \mathrm{C}, 62.84 ; \mathrm{H}, 6.71 \%$.

Compound XII. Oil; $m / e$ 210; IR $\underset{\max }{\mathrm{Lia}} 1730,1260 \mathrm{~cm}^{-1}$; UV $\lambda_{\max }^{\mathrm{MeOH}} 210 \mathrm{~nm}$ shoulder at 240

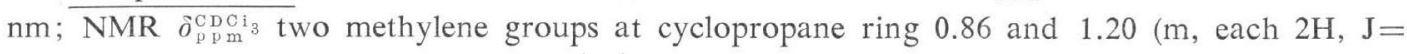
10.0, 4.0 and $3.0 \mathrm{~Hz}), 3.08\left(\mathrm{~s}, 1 \mathrm{H},-{ }^{\mathrm{C}}-\mathrm{C}-\mathrm{C}-\mathrm{H}-\mathrm{COOCH}_{3}\right)$, and $3.73\left(\mathrm{~s}, 3 \mathrm{H},-\mathrm{COOCH}_{3}\right)$. Found: C, 62.55; $\mathrm{H}, 6.79 \%$. Calcd. for $\mathrm{C}_{11} \mathrm{H}_{14} \mathrm{O}_{4}$ : C, 62.84; H, $6.71 \%$.

Compound XXVII. Alkaline degradation of compound VIII afforded compound XXVII. Compound VIII $(250 \mathrm{mg}$ ) was dissolved in $10 \mathrm{ml}$ of $1 \mathrm{~N} \mathrm{NaOH}$ in $50 \%$ aq. $\mathrm{MeOH}$ and left for 30 minutes at $50^{\circ} \mathrm{C}$. After evaporation of the reaction mixture under reduced pressure, the concentrate was extracted with ether and purified on a preparative thin-layer plate of silica gel developed with benzene and eluted with EtOAc $(148 \mathrm{mg})$; colorless oil $m^{\prime} \boldsymbol{e}$; 198; IR $\nu_{\max }^{\mathrm{CHCl}_{3}} 1750, \quad 1710 \mathrm{~cm}^{-1} ; \quad \mathrm{NMR} \quad \delta_{\mathrm{pDm}}^{\mathrm{CDCl}_{3}} 1.03\left(\mathrm{~d}, 3 \mathrm{H}, \quad-{ }^{\mathrm{CH}} \mathrm{C}-\mathrm{CH}_{3}, \quad \mathrm{~J}=8.0 \mathrm{~Hz}\right), \quad 1.67 \quad(\mathrm{~s}, \quad 3 \mathrm{H}$, 
$\left.-\stackrel{\mathrm{C}}{\mathrm{C}}(\mathrm{OH})-\underline{\mathrm{CH}}_{3}\right) \quad 2.00 \quad\left(\mathrm{~s}, 3 \mathrm{H},-\mathrm{C}\left(\underline{\mathrm{CH}}_{3}\right)=\right), 2.66 \quad\left(\mathrm{q}, 1 \mathrm{H},-\underline{\mathrm{CH}}-\mathrm{CH}_{3}, \mathrm{~J}=8.0 \mathrm{~Hz}\right), 3.66 \quad(\mathrm{~s}, 3 \mathrm{H}$,

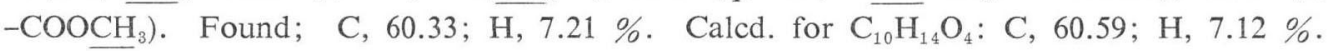

Compound XXX. Compound III was refluxed in $30 \% \mathrm{NaOH}$ solution for 3 hours and

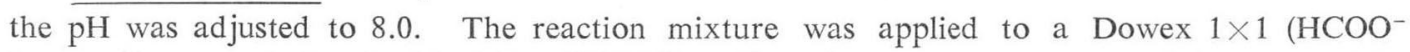
form) column and eluted with $0.5 \mathrm{~N} \mathrm{HCOOH}$. The eluate was concentrated in vacuo. The residue was crystallized from a mixture of EtOH and EtOAc. Thus compound XXX was ob-

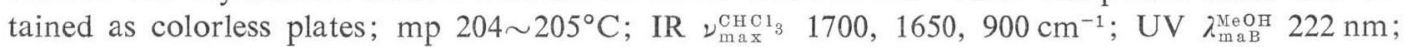
NMR $\delta_{\mathrm{ppm}}^{\mathrm{DMSO}_{6}} 2.14(3 \mathrm{H}), 6.64(1 \mathrm{H})$. Found: C, 46.42, H, 4.72\%. Calcd. for $\mathrm{C}_{5} \mathrm{H}_{6} \mathrm{O}_{5}: \mathrm{C}$, $46.16 ; \mathrm{H}, 4.65 \%$.

\section{Acknowledgement}

The authors wish to express their sincere thanks to Mr. H. Kuwano, Central Research Laboratories, Sankyo Co., Ltd., for the measurement and analysis of the NMR spectrum.

\section{References}

1) Haneishi, T.; N. Kitaitara, Y. Takiguchi, M. Arai \& S. Sugawara: New antibiotics, methylenomycins A and B. I. Producing organism, fermentation and isolation, biological activities and physical and chemical properties. J. Antibiotics 27: 386 392, 1974

2) Hauptman, H. \& J. Karle: Structure invariants and seminvariants for non-centrosymmetric space groups. Acta. Cryst. 9: 45 55, 1956 